\title{
ХУДОЖНЬО-ЗОБРАЖАЛЬНА РОЛЬ АВТОРСЬКИХ НЕОЛОГІЗМІВ У ФОРМУВАННІ ПИСЬМЕННИЦЬКОГО ІДІОСТИЛЮ
}

\author{
ІРИНА БАБІЙ \\ Тернопільський національний педагогічний \\ університет імені Володимира Гнатюка, \\ Тернопіль - Україна \\ ARTYSTYCZNO-FIGURATYWNA ROLA \\ NEOLOGIZMÓW AUTORSKICH \\ W KSZTAŁTOWANIU INDYWIDUALNEGO STYLU PISARZA \\ IRYNA BABIJ \\ Tarnopolski Narodowy Uniwersytet Pedagogiczny im. W. Hnatiuka, \\ Tarnopol - Ukraina
}

STRESZCZENIE. Przedmiotem rozważań niniejszego artykułu są neologizmy autorskie jako składniki stylotwórcze w tekstach artystycznych na podstawie utworów Mychajła Stelmacha. Dokonano analizy semantyki oraz osobliwości funkcjonowania innowacji leksykalnych. Ustalono rolę neologizmów autorskich w kształtowaniu indywidualnego stylu pisarza.

\section{ARTISTIC-FIGURATIVE ROLE OF AUTHOR'S NEOLOGISMS IN THE FORMATION OF A WRITER'S INDIVIDUAL STYLE}

\author{
IRYNA BABIY \\ Volodymyr Hnatiuk Ternopil National Pedagogical University, \\ Ternopil - Ukraine
}

ABSTRACT. The article deals with the individual author's neologisms as style creating component in fiction on the material of Mykhailo Stelmah's works. The semantic and functional features of lexical innovations have been analyzed. The role of author's neologisms in the formation of the writer's individual style has been considered.

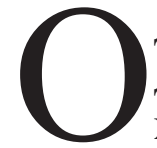

дним із актуальних питань сучасної лінгвістики вважається питання про дослідження індивідуально-авторських неологізмів. Лексичні інновації художнього тексту — важливий естетичний компонент авторської картини світу письменника. Індивідуально-авторська словотворчість є джерелом збагачення письменницької мови. С. Срмоленко з цього приводу зазначає: „Хоч письменник і користується загальновживаною мовою, проте його індивідуальне світосприймання, психологія мовотворчості зумовлюють витворення особливого мовного світу". Естетично вагомим елементом творення цього особливого мовного світу і $€$ індивідуально-авторські новотвори як наслідок письменницьких творчих пошуків, результат поєднання авторського неординарного мислен-

${ }^{1}$ С. С рмолен но, Нариси з украӥнської словесності (стилістика та культура мови), Київ 1999, c. 305. 
ня, доброго естетичного смаку, творчої уяви та індивідуального бачення і сприйняття довкілля. Щоправда, не кожному письменнику притаманне мистецтво творити нові слова. Відомим словотворцем у царині індивідуально-авторської номінації вважають М. Стельмаха. Творчість цього художника слова „вражає багатством барв, неймовірними щедротами мовностилістичних засобів; щедро черпаючи з фольклору, письменник мовби витворює свій власний ,літературний фольклор", завдяки чому сторінки його книжок буквально приголомшують буйною метафоричністю, квітучістю слова, високою образністю"2 .

Творчість М. Стельмаха жанрово різноманітна й потребує грунтовного наукового вивчення. У центрі нашої уваги - індивідуально-авторське словотворення письменника. У сучасній філологічній літературі до цього часу відсутні монографічні дослідження, присвячені аналізу лексичних інновацій М. Стельмаха. Це й зумовлює актуальність запропонованої розвідки.

Предметом розгляду обрано індивідуально-авторські лексичні інновації М. Стельмаха, а матеріалом слугують його прозові твори (романи Хліб $i$ ciль, Правда і кривда, Чотири броди, автобіографічні повісті Гуси-лебеді летять і Щедрий вечір).

Мета дослідження — опис семантики та особливостей функціонування індивідуально-авторських неологізмів у художньому мовленні М. Стельмаха, 3’ясування ролі неолексем у формуванні письменницького ідіостилю.

В останні десятиліття в сучасній українській та зарубіжній лінгвістиці пожвавився науковий інтерес до індивідуально-авторських неологізмів, які дослідники розглядають у різних аспектах: лексико-семантичному, ономасіологічному, словотвірному, лексикографічному тощо. Проблемі індивідуальноавторської номінації присвячені праці таких мовознавців, як Г. Винокур, Г. Вокальчук, В. Герман, Л. Данилова, С. Єрмоленко, О. Земська, Ж. Колоїз, О. Кубрякова, О. Ликов, В. Лопатін, В. Русанівський, О. Стишов, Н. Сологуб, В. Чабаненко та ін.

Індивідуально-авторські неологізми як позасистемні мовленнєві явища, що зберігають індивідуальне в основі своєї появи, посідають значне місце в художньому дискурсі. Більш природною сферою їхнього функціонування є, звичайно, поетичне мовлення, однак і в прозі активно народжуються експресивно забарвлені лексичні інновації.

Авторські неологізми характеризуються низкою диференційних ознак. О. Ликов виділяє дев'ять таких ознак: ,1) належність до мовлення, 2) утворюваність (невідтворюваність), словотвірна похідність, 4) ненормативність, 5) функціональна одноразовість, 6) експресивність, 7) номінативна факультативність, 8) синхронно-діахронна дифузність, 9) індивідуальна належність"з.

„Основною диференційною ознакою неологізму” Ж. Колоїз уважає „його відносну новизну: нове настає за чимось іншим щодо нього в часі, відображає не раптовий, короткочасний зріз об' єктивної вербальної дійсності, а протяжність у мовному просторі”, що є різною для різних матеріальних репрезентантів"4.

Більшість науковців дотримується погляду, що основними ознаками оказіональних слів є індивідуальність їх творення, стилістичне навантажен-

${ }^{2}$ Наш Михайло Стельмах: Літературно-критичні статті, етюди, есе, Київ 1982, с. 11.

${ }^{3}$ А. Г. Л ыков, Современная русская лексикология (русское окказиональное слово), Москва 1976, c. 11.

${ }^{4}$ Ж. В. Колоїз, Оказіональна дериваиія: теоретичний та функиіонально-прагматичний аспекти, Автореф. дис. докт. філол. наук, Київ 2007, с. 7. 
ня, тимчасовість існування, прозорість значень та ін. На думку Р. Намітокової, найвагоміша серед названих ознак — „ознака індивідуальності їх утворення, ознака авторства слова"5.

На позначення цих мовних одиниць у неологічній літературі лінгвісти застосовують понад тридцять термінів (,авторський неологізм”, „лексичний новотвір”, „художній неологізм”, „лексична інновація”, ,лексичний новотвір”, „,індивідуально-авторський новотвір”, „слово-метеор”, „,слово-саморобка”, „слово-експромт”, „,слово-беззаконник”, „оказіоналізм”, „оказіональне слово”, „неолексема”, ,індивідуалізм” та ін.). В. Лопатін уважає, що „кожен із запропонованих термінів по-своєму виправданий, характеризує явище зі свого боку, зі свого погляду, й тим самим воно одержує різнобічне висвітлення"6. Той факт, що буває важко розмежувати узуальні лексеми та неузуальні, довести оказіональність виявлених одиниць і под., і спричинює розбіжність у термінології, відсутність єдиного загальноприйнятого визначення цих лексем, а також єдності в їх теоретичному висвітленні.

У сучасній лінгвістиці дослідники досить активно застосовують термін „оказіоналізм”, „оказіональне слово”. На думку Л. Данилової, термін „оказіоналізм” — „найбільш вдалий, на відміну від „індивідуальний неологізм”, „,слова-саморобки”, „поетичний неологізм”, „неологізм контексту” та ін. У ньому досить ясно визначена специфіка подібних слів, утворених конкретним автором з метою „обслуговувати мінімальний контекст, певний приватний випадок, певну мовленнєву ситуацію; ці слова не претендують на те, щоб закріпитися в мові, увійти до загального вжитку"7.

Термін „оказіональне значення” вперше вжив німецький філолог Г. Пауль 1880 р. у праці Принщипь истории языка, де дослідник зіставляє поняття узуальності й оказіональності: „Узуальне значення розуміємо як усю сукупність уявлень, що складають для члена певної мовної спільності зміст даного слова, оказіональне значення — ті уявлення, які мовець пов'язує із цим словом у момент його вимови і які, як він уважає, зв'яже, у свою чергу, й слухач із цим словом".

О. Турчак зауважує, що ,за останні півстоліття погляди на природу й сутність оказіоналізмів зазнали істотних змін, але й до цього часу в мовознавстві серед новотворів традиційно виділяють три типи: неологізми, оказіоналізми й потенційні слова",

У сучасній науці поширена думка про те, що оказіональні слова - це такі, які ,утворюються за наявними в мові моделями, але не використовуються в загальновживаному словнику. Оказіоналізми мають індивідуальний характер, уживаються тільки в умовах певного контексту, що дає змогу розкрити їхнє значення" ${ }^{\prime 0}$. Г. Вокальчук наголошує, що до індивідуально-авторських номінацій

${ }_{5}^{5}$ Р. Ю. Нам итокова, Авторские неологизмыл: словообразовательный аспект, Ростов-наДону 1986, с. 19.

${ }^{6}$ В. В. Лопатин, Рождение слова. Неологизмы и окказиональные образования, Москва 1973 , с. 64.

7 Л. В. Дан и л о в а, К вопросу об окказионализмах и способах их образования (на материале поэзии А. Вознесенского, Е. Евтушенко, Р. Рождественского), [в:] Стилістика художественного текста, Межвуз. сбор. науч. тр., Фрунзе 1984, с. 89.

${ }^{8}$ Г. Пауль, Принциипь истории языка, Москва 1960, с. 94.

${ }^{9}$ О. Турч ак, Оказіоналізми як об'єкт лінгвістичного дослідження, [в:] „Українська мова”, 2004, № 2, c. 49.

${ }^{10}$ С. Я. Срмоленко, С. П. Бибик, О. Г. Тодор, Украӥнська мова. Короткий тлумачний словник лінгвістичних термінів, Київ 2001, с. 113. 
„доцільно зараховувати не лише слова, утворені в результаті структурних і семантичних змін вихідних одиниць, але й ті, що є своєрідними авторськими видозмінами узуальних лексем, повністю збігаючись із ними у значенні"11. Особливістю авторських неологізмів у художньому тексті $\epsilon$ те, що вони, як правило, крім номінативного значення, репрезентують емотивно-експресивне забарвлення, сприяють формуванню письменницького ідіолекту, увиразнюють індивідуально-авторське мовлення. Лексичні новотвори можуть створюватися за традиційними словотвірними моделями, а можуть - i за незвичними, невластивими українській мові словотвірними зразками і 3 порушенням мовних норм. Тому оказіональні одиниці „,варто розглядати як складне явище системного (реалізація словотвірних можливостей, закладених у системі певної мови) й асистемного (ненормативність, функціональна й емоційна, й емоційноекспресивна зумовленість, створення для ситуативних потреб) характеру"12.

Індивідуально-авторські неологізми з'являються під впливом і мовних, і позамовних чинників. Смисловий обсяг та функціональна значущість неолексем у контексті настільки широкі, що їхня семантична структура може містити не тільки пряму, безпосередню номінацію описуваної реалії, а й додаткові смислові компоненти, що можуть презентувати національно-духовний і лінгвокультурний потенціал певної мови. У художньому мовленні індивідуально-авторські неологізми, як правило, емоційно й експресивно зумовлені, тому вони нерідко $\epsilon$ естетично вагомим компонентом авторського образотворення та формування письменницького ідіостилю.

Під поняттям ,,індивідуальний стиль”, ,ідіолект” розуміють „сукупність мовно-виражальних засобів, що виконують естетичну функцію і вирізняють мову окремого письменника 3-поміж інших; своєрідність мови окремого індивіда. Це поняття насамперед стосується стилю майстра слова, письменника. Індивідуальний стиль залежить від творчої особистості автора, його світосприймання та світовідчуття, ставлення до явищ навколишньої дійсності та оцінки їх"13. На думку Н. Сологуб, „художнє мовлення вимагає не лише майстерного використання словникового багатства мови, якою пише письменник, а й пошуку індивідуальних форм вираження ідейно-художнього задуму письменника. Митець може відчувати недостатність засобів художнього пізнання, їхню обмеженість, що стимулює пошук нових слів в естетичному освоєнні світу. Цей пошук виражається в індивідуальному словотворенні письменника"14. Індивідуально-авторські новотвори в художньому тексті мають здатність бути таким компонентом, що, завдяки своїй оказіональності, незвичній семантиці та естетичній вазі, дає змогу письменнику відтворити авторську МКС, досягнути ідейно-художньої довершеності художнього твору. Авторські лексичні новотвори є вагомим стилетвірним засобом.

3 виразними естетичними настановами вживає індивідуально-авторські неологізми М. Стельмах. Вони органічно вплетені в словесну тканину твору, виконують важливу текстотвірну функцію. Цікавою й самобутньою $є$ вся різножанрова творчість М. Стельмаха, що презентує оригінальний ідіолект письменника. У творах М. Стельмаха корпус індивідуально-авторських неоло-

${ }^{11}$ М. Вокальчук, Словотворчість украӥнських поетів ХХ століття, Острог 2008, с. 64.

${ }^{12} \mathrm{O}$. А.С т и ш о в, Украӥнська лексика кіния ХХ століття (на матеріалі мови засобів масової інформації), Київ 2005, с. 47.

${ }_{13}$ Українська мова: Енциклопедія, редкол.: В. М. Русанівський, О. О. Тараненко та ін., Київ 2000, с. 603-604.

${ }^{14}$ Н. М. С ол о гу б, Мовний світ Олеся Гончара, Київ 1991, с. 88. 
гізмів становить близько півтори тисячі лексичних інновацій. За граматичними характеристиками вони належать до чотирьох основних самостійних частин мови: іменника, прикметника, дієслова та прислівника; найбільше - іменників і прикметників.

Іменникові лексичні неологізми М. Стельмаха можна об'єднати в кілька лексико-семантичних груп, найчисленнішу становлять назви осіб за такими ознаками: 1) рід занять, діяльність: горшкограй, відвідувач-медоїд, крамарпройда, професор-життєлюб, звіздоноша, оратор-дурисвіт, папероїд, перошкряб, куховарка-зводниия та ін.; 2) внутрішні (характерологічні) якості, властивості: брехуненко, пошкодерник, безпардонник, кислій, головодур, жеребило, мимрач, скритник, спритняга, осудець, заздренник, гонивітер, лискуха, лічикруп, продайдуша, носодер, сушиголова, мамлюк, нудисвіт, фицькало, язикань (балакучий), захвойданка, ложкохват, кручений-верчений, людозвір, кроволюб та ін.; 3) розумові здібності: тупоум, нерозумець, безклепка, недотямко, нерозсудливець, бездар, пришелепок, мудригайло, простюха та ін.; 4) зовнішній вигляд, риси портрету: дебеляк, дужень, задрипа, волохань, босоніг, (босоногий хлопець) та ін. 5) соціальний стан, матеріальне становище: злидар-невдалиия, шляхтич-однодворещь, дрантогуз (бідняк), голодраби (бідняки), комзлидні (бідняки), голоп'ятник, архікнязь та ін.; 6) вік, значення недорослості: верескля, лебеденко, чадунь (від чадо) та ін.

Крім назв осіб, в авторському лексиконі М. Стельмаха наявні ще такі семантичні групи іменникових інновацій, як назви: 1) рослин, плодів тощо: дуб-довговік, изар-колос, дивдерево, верба-підліток; 2) тварин, птахів: конінеуки, блохотрус (собака), окунці-матросики, дзьобаха та ін.; 3 ) предметів, машин, речовин, продуктів харчування тощо: книги-романи, нежурниця (горілка); 4) явищ та станів природи тощо: роса-сльоза, місящь-білогривещь, дідусь-місящь, сонцееграй, осмерк та ін.

Велику групу складають назви абстрактних понять: 1) емоцій, почуттів, відчуттів, психічного стану особи: засмута, печаль-журба, диво-радість, надія-безнадія, жалі-тривоги, кволість-знемога, n'янкість та ін.; 2) якостей, внутрішніх властивостей особи: твердосердність, жорстокосердя, гидомирство, бабодурство, худобство, холодноокість, честивість та ін.; 3) мисленнєвих процесів: розмисл, жаль-думка, аргомисль та ін.; 4) дій, процесів та їх результатів: підмова-облуда, вертійство, мочемордіє, лихомовство, клопотарство, підшепіт, колінкування, лементація, старостування-правування та ін.

Індивідуально-авторські лексичні новотвори М. Стельмаха, як правило, мають прозору семантичну та дериваційну структуру. Переважну їх більшість утворено від узуальних слів за словотвірними моделями, характерними для української мови.

Ідіостилю М. Стельмаха притаманне активне вживання індивідуально-авторських номінацій особи. Часто вони містять оцінне значення і $є$ вагомим естетичним засобом характеротворення персонажів. Водночас такі неолексеми презентують авторське бачення героїв та його ставлення до них, напр., доброзичливо, із симпатією М. Стельмах описує працьовитих селян-трудівників: заповзятець, дужень; i, навпаки, свою зневагу до брехунів, підлих, злодійкуватих героїв виражає за допомогою неолексем: брехуненко, кривосудець, слизькоумецьь, нелюдько, окаянниця, безчесник, ложкохват, панич-пролаза, виплідок, напівхудобина та ін. 
Авторські новотвори, що містять негативну оцінність, становлять численну групу й виконують оцінно-експресивну роль у контексті твору, напр.: - Одумайся, Семене. Нащо тобі цей гріх, коли ти чоловік, а не продайдуша 15 (Чотиpu броди); - Чого не знаю, того не знаю, тільки в душі й очах померкло, бо людозвір не пожаліє нас, - навмисне говорить політично для Кундрика (Чотири броди) та ін. Часто такі неолексеми утворені від твірних слів зі зниженим стилістичним забарвленням: гнилюк, гнидюк, вибрудок, посміття, дрантюх та ін.

Особливістю індивідуального словотворення М. Стельмаха $є$ те, що письменник сам мотивує семантику неолексем, напр.: „Ох і зажера ви! Такого лічикрупа ще світ не бачив” (лічикруп — „скупий”); „І пам’ятай: усякій людині, при охоті, можна обламати крила. — Я й не знав, що ти такий криложер" (значення іменника криложер виводиться із зазначеної фраземи обламати кри$л а)$; - От ходім до хати, я тобі й розповім про цього випортка, що тільки й знає — лічити чужі гроші й гріхи; <...> Він же, вибрудок, одразу трьом жінкам голову морочить, а тепер на четверту, чи на їі воли, накинув більма (Чотири броди). Такими коментарями автор презентує й підсилює оцінно-експресивну характеристику персонажа.

Показовим для індивідуально-авторського образотворення М. Стельмаха $є$ те, що створені автором неолексеми можна об'єднати в синонімічні ряди, порівн.: жорстоку людину характеризують новотвори людозвір, кроволюб, жорстокосердеиь; хитру — кручений-верчений, слизькоумеиь; нерозумну - безклепка, тупоум, нерозумець, одуркуватий; бідну - дрантогуз, комзлидня, голоп'ятник, голодраби; чоловіка-бабія - бабодур, жеребило, гріхоплут, головодур та ін.

Корпус оказіональних прикметників письменника відіграє виразну художньо-зображальну роль в авторському характеротворенні. Прикметникові неологізми характеризують особу, предмет чи явище за різними ознаками:

1) зовнішній вигляд (портрет): бестіальні очі, гарбузисте обличчя, дебелястий, прицюцькуватий, корчкуватий Павло Шаламай, студеноокий, грубовусий батько, невнятноликий, довгощокий, важкотілий, гніздоподібне обличчя, линялочубий Григір, тарілощока бублейниця Стефа, кротоподібний, тяжскобровий та ін., напр.: - Але ж... береться жалем усе гніздоподібне обличчя завзятого мисливця (Хліб і сіль); На його тупоскулому, кавуноподібному обличчі, як на воском залитій книзі, застигає пошана до своєї особи (Хліб і сіль);

2) розумові здібності: безклепкий, розумноокий, малокебетний, дурноп 'ятий, блякло-манірні поети та ін., напр.: <..> щоб збирати < ..> гомін і відгомін справжньої поезії, від якої, мов од мужицької сорочки, відцурались блякломанірні поети (Хліб і сіль);

3) внутрішні якості, риси характеру, психологічний стан: оборотистий, пройдошний, ледачкуватий, хамлуватий, заздренний, черствозубий, лютобровий, дрібносовісний, хмуроокий, веселоротий, скрипливобровий, дрімливо-покірний, радісно-здивований, тихомрійний, скорботно-терплячий, весело-лихий, веселоиікавий, бестіально-хитрий та ін., напр.: <...> послухався тоді скрипливобрового батька і не одружився (Дума про тебе); < ..> стер із обличчя заклопотаність, і воно одразу стало догідливо-лагідним, уважним (Дума про тебе);

4) предмети, одяг тощо: ненаський одяг, передпотопний, решетоподібний картуз, тупоморда гармата та ін.;

${ }^{15}$ Тут і далі цитати наводимо за таким виданням: М. С тел ь м ах, Твори в 7 m., Київ 1983. 
5) характеризують групи людей, певні угруповання: многоцінне товариство, воскоголова дітвора, розсукині діти; перчистий, веселочубий рід. Як правило, такі прикметники мають оцінно-експресивне забарвлення;

6) явища природи, її стан: грізнофіалкові хмари, димчасто-рожсеві хмари, срібнозернистий перелив снігів та ін.;

7) рослинний і тваринний світи: лискучолистий барвінок, вікодавній ліс, волохатоокий жовтець, розгілясті груші-глеки, веселоокий птах та ін.;

8) абстрактні назви: дурноколінний глум, ласкаво-улеслива догідність, нервово-обурений плач, кроволюбне яничарство, ідіотсько-сентиментальна звичка, винувато-радісна посмішка, благодушно-нетерплячий настрій очікування, тихошелесна північ, злобно-похмурі погляди та ін. Такі прикметникові лексичні інновації мають композитну форму і в художньому тексті виконують емотивно-експресивну роль, оскільки характеризують, як правило, психологічний стан персонажів, їхній настрій;

9) колір, забарвлення: холодно-блакитнавий, гнітючо-сірий, біло-рожсевоблакитний день, холодно-сірий та ін. Такі кольоронайменування складаються в основному 3 двох компонентів, рідко - трьох. Часто ці композити містять суб'єктивно-оцінювальний компонент;

10) одоративні та смакові властивості: приторно-пахучі покої, відволоженокисла глина й цзвіль та ін.

Прикметникові новотвори є вагомим емотивно-експресивним та оцінним засобом у художньому світі М. Стельмаха: вони точно виражають авторський задум.

В індивідуально-авторському лексиконі письменника меншу групу, ніж іменникову й прикметникову, становлять дієслівні новотвори, які можна об'єднати в лексико-семантичні групи зі значенням:

1) „набувати певного кольору, забарвлення”: блакитнавитися, тінявитися та ін.;

2) „певної характеристики за природними явищами, предметами”: роситися, вичервлюватись, ядерніти та ін.;

3) „певної характеристики за зовнішнім виглядом”: напатлувати, виделікатніти та ін.;

4) „виявляти емоції, реалізувати внутрішні характеристики”: напанитись, перешерститись, посовіститися, споневажсати, напухиритись, помедовіти та ін.;

5) „фізичний / фізіологічний стан об'єкта": банькатити, занезграбитись та ін.;

6) „види руху, переміщення в просторі”: телембаситись, шнуркувати, підгуцинкувати та ін.;

7) „характеризувати процес говоріння, мовлення, вимову, звучання": шкварготіти, гудіти, реготіти, зашегерявити, викахикувати, тюгикнути, заюрликати, бриніти-густи, заскрипіти-заспівати.

Широку лексико-семантичну класифікацію дієслівних оказіоналізмів подали О. Стишов і Г. Вокальчук.

У процесі творення дієслівних авторських інновацій продуктивними є змішані афіксальні способи словотворення (префіксально-суфіксальний, суфіксально-постфіксальний, префіксально-суфіксально-постфіксальний і под., що є суто дієслівними способами деривації) та словоскладання.

Показово, що дієслівні новотвори М. Стельмаха, як правило, є семантично прозорими: в художньому тексті вони уточнюють, конкретизують дію, ознаки по- 
значуваних об'єктів дійсності. Нерідко ці неолексеми містять виразне емоційноекспресивне забарвлення, напр.: покваснішало на душі, зжсліснів мій голос.

В авторській мовній палітрі М. Стельмаха невелику групу становлять оказіональні прислівники. Переважно це прості за структурою слова (поскляніло, навмани та ін.), рідше - складні (хильцем-хильцем, дурно-пусто та ін.).

У творах М. Стельмаха $є$ авторські неологізми, утворені на основі актуалізації вигуків, напр.: тьху-тьхукання, одгетькувати (відмахуватись од чогось) та ін.

Отже, авторські лексичні неологізми - невід'ємний естетично вагомий компонент формування письменницького ідіостилю. Індивідуальноавторська номінація є джерелом збагачення письменницької мови. Наявність оказіоналізмів на сторінках художніх творів свідчить про самобутність та мистецьку оригінальність ідіостилю їхнього автора, багатство його індивідуальнообразного мислення. 